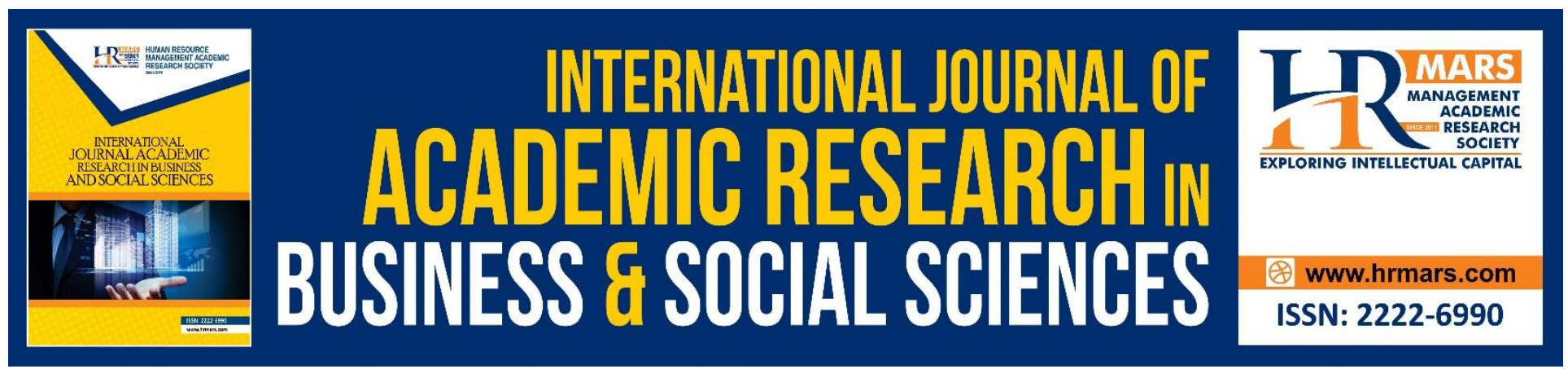

\title{
Assessing Small-Scale Youth Fishermen Adaptation Ability towards Climate Change
}

Nurul Farhana Saharrudin, Asnarulkhadi Abu Samah, Jeffrey Lawrence D'Silva, Hayrol Azril Mohamed Shaffril

To Link this Article: http://dx.doi.org/10.6007/IJARBSS/v8-i9/4661

DOI: $\quad 10.6007 /$ IJARBSS/v8-i9/4661

Received: 19 August 2018, Revised: 11 Sept 2018, Accepted: 29 Sept 2018

Published Online: 15 October 2018

In-Text Citation: (Saharrudin, Samah, D’Silva, \& Shaffril, 2018)

To Cite this Article: Saharrudin, N. F., Samah, A. A., D’Silva, J. L., \& Shaffril, H. A. M. (2018). Assessing Small-Scale Youth Fishermen Adaptation Ability towards Climate Change. International Journal of Academic Research in Business and Social Sciences, 8(9), 870-879.

\section{Copyright: (C) 2018 The Author(s)}

Published by Human Resource Management Academic Research Society (www.hrmars.com)

This article is published under the Creative Commons Attribution (CC BY 4.0) license. Anyone may reproduce, distribute, translate and create derivative works of this article (for both commercial and non-commercial purposes), subject to full attribution to the original publication and authors. The full terms of this license may be seen

at: http://creativecommons.org/licences/by/4.0/legalcode

Vol. 8, No. 9, September 2018, Pg. 870 - 879

Full Terms \& Conditions of access and use can be found at http://hrmars.com/index.php/pages/detail/publication-ethics 


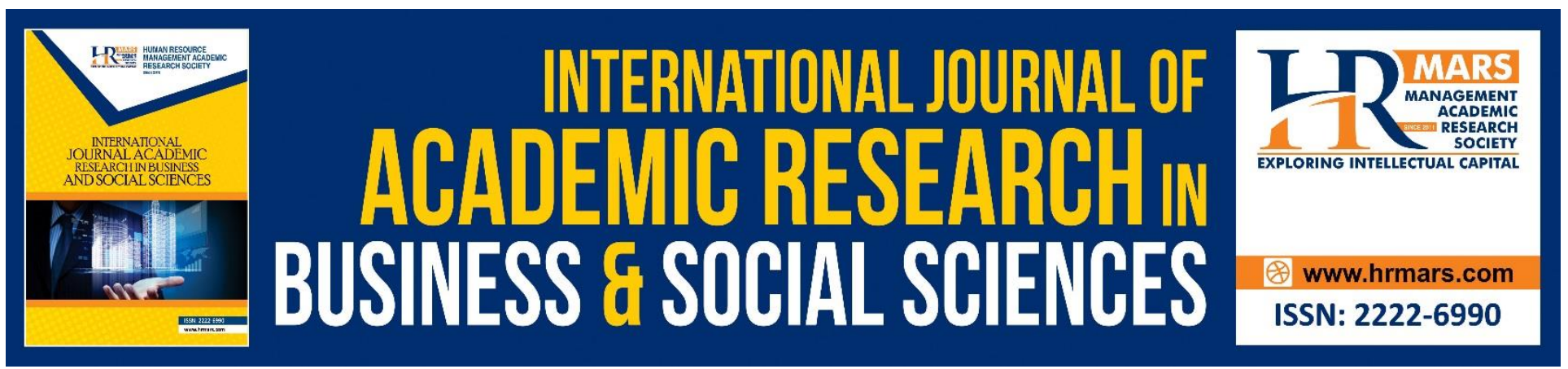

\title{
Assessing Small-Scale Youth Fishermen Adaptation Ability towards Climate Change
}

\author{
${ }^{1}$ Nurul Farhana Saharrudin, ${ }^{1,2}$ Asnarulkhadi Abu Samah, \\ ${ }^{1}$ Jeffrey Lawrence D'Silva, ${ }^{1}$ Hayrol Azril Mohamed Shaffril \\ ${ }^{1}$ Institute for Social Studies, Universiti Putra Malaysia \\ ${ }^{2}$ Faculty of Human Ecology, Universiti Putra Malaysia
}

\begin{abstract}
This study aims to assess the adaptation ability towards climate change among youth small-scale fishermen. This study is quantitative in nature whereby via a multistage cluster sampling, a total of 203 respondents from four fisheries districts had been selected. The resulted analysis confirmed small-scale youth fishermen strong attachment to place and area, strong environmental awareness, values and attitudes, and strong formal and informal networks. The resulted analysis also confirmed their weakness to adapt in relation to employability, business size, and approach and livelihood diversity. Several recommendations are made for concerned agencies, which are to focus on exposing small-scale youth fishermen towards advanced fisheries technologies, to provide entrepreneurship opportunities, to advise them on good financial planning and management, and financial assistance. Keywords: Agricultural and Fishing Industries, Climate Change Impacts, Youth Fishermen, Fisheries Industry, Adaptation Ability.
\end{abstract}

\section{Introduction}

Climate change occurs slowly over time. Certainly, this phenomenon is expected to worsen in the future and relentlessly affect various aspects of life (IPCC, 2007; Muhammad et al., 2016). Among the obvious climate change impacts are the rise in temperature and unstable shifting seasons (Kwan et al., 2011; Suhaila et al., 2010). The rise in temperature has caused the ice and glaciers in the North and South Pole to melt. The phenomenon causes mass expansion of sea water and sea level rise, which eventually decreases the production of certain fish species and shrimp ponds as well as threatens the lives of coastal communities (Badjeck et al., 2009; Roessig et al., 2004). The threats of global climate change has become a concern of the international community as it badly affects their socio-economic routine, especially those who heavily rely on nature stability (Shaffril et al., 2015; Tanggang et al., 2012). 
INTERNATIONAL JOURNAL OF ACADEMIC RESEARCH IN BUSINESS AND SOCIAL SCIENCES Vol. 8, No. 9, Sept. 2018, E-ISSN: 2222-6990 @ 2018 HRMARS

Youth fishermen are among the affected groups as their reliance on weather and environmental stability is high. Referring to Shaffril et al. (2017), extreme waves and strong winds increase the risks of conducting fishery activities and it badly affects the small-scale fishermen who are merely equipped with a small sized vessels and small engine capacity. Additionally, results from such phenomena have brought damage to the fishermen facilities (jetty, fishing tools) and erode coastal and mangrove areas. Both Shaffril et al. (2017) along with Shaffril et al. (2016) further clarified the effects of rising temperature altered the quantity, quality and habitat (coral reef) of marine fauna, which later impede fishermen income generating activities.

As the impact of climate change are expected to worsen in the future (IPCC, 2007), the best response towards it would be adaptation towards its impacts. Adaptation according to the National Policy on Climate Change is

Actions taken to help communities and ecosystem to cope with actual or expected

impacts of climate change (Ministry of Natural Resources and Environment, 2009)

A study on youth fishermen adaptation ability is vital as they are the future generation who are expected to face the climate change consequences. Having more relevant studies will inform the concerned parties on possible strategies and adaptation plans that are in line with their needs, abilities, and interests. Despite the mounting needs to develop adaptation strategies, the number of existing studies are frustrating low. Although studies on fishermen adaptation ability towards climate change are available by Shaffril et al. (2017); Shaffril et al. (2016), Abu Samah et al. (2016), Shaffril et al. (2015), D'Silva et al. (2012), most of these studies rather focused on the general community of fishermen and only a few have placed their focus specifically on youth fishermen. This study tries to fill the gap by aiming to measure the adaptation ability of small-scale youth fishermen towards the impact of climate change.

\section{Methodology}

Research Design

This research uses a quantitative method, in which the instrument is in the form of a survey and it was used as the main tool for data collection process.

Instrument development

The instrument was prepared based on reviews of literature. It consists of three main parts, namely, demographic (seven questions), fishery activities background (eight questions) and the aspects of adaptation capacity towards climate change among small-scale youth fisherman (95 questions). Under the demographic section and fishery activities background, the respondents were given an open-ended and close-ended options for answer, while in the remaining parts, the respondents were given a five-point Likert-type scale ranging from 1 (strongly disagree) to 5 (strongly agree).

Research area and sampling

Based on a multi-stage cluster sampling, four fisheries districts had been selected, namely, Batu Pahat (Johor) Pengkalan Chepa (Kelantan), Kuantan (Pahang) and Setiawan (Perak). From these four districts, a total of 203 youth fishermen aged between 18 to 40 years old were selected as respondents (in line with the definition of youth age at a national level).

Data collection 
INTERNATIONAL JOURNAL OF ACADEMIC RESEARCH IN BUSINESS AND SOCIAL SCIENCES

Vol. 8, No. 9, Sept. 2018, E-ISSN: 2222-6990 @ 2018 HRMARS

The data collection process was conducted from September 2016 to October 2016. The main method of data collection was survey. The data collection process was conducted by the researchers and assisted by a number of experienced and trained enumerators. On average, 25 minutes were allocated for each respondent in the survey process.

\section{Result and Discussion}

Demographic finding

Table 1 demonstrates the respondent's demographic factors. All the studied areas are represented by an equal number of respondents. A majority of the respondents were Malay (96.1\%) and men (99.0\%). The mean score recorded for respondent's age was 32 years old as the majority of them (63.1\%) fall within the 31 to 40 years old age group. A majority of the respondents have possessed a moderate education achievement as $30.5 \%$ and $38.4 \%$ of them hold a lower and upper secondary achievement. More than half of them were married (57.6\%) and $35.0 \%$ of them had at least 4 to 5 household members.

Table 1: Respondents' demographic data

\begin{tabular}{|c|c|c|c|}
\hline Factor & Frequency & Percentage & Mean \\
\hline \multicolumn{4}{|l|}{ Fisheries districts } \\
\hline BatuPahat & 50 & 24.6 & \\
\hline Pengkalan Chepa & 51 & 25.2 & \\
\hline Kuantan & 52 & 25.6 & \\
\hline Setiawan & 50 & 24.6 & \\
\hline \multicolumn{4}{|l|}{ Race } \\
\hline Malay & 195 & 96.1 & \\
\hline Chinese & 8 & 3.9 & \\
\hline \multicolumn{4}{|l|}{ Gender } \\
\hline Male & 201 & 99.0 & \\
\hline Female & 2 & 1.0 & \\
\hline Age group (years) & & & 32.01 \\
\hline$<30$ & 75 & 36.9 & \\
\hline $31-40$ & 128 & 63.1 & \\
\hline \multicolumn{4}{|l|}{ Education achievement } \\
\hline Never been to school & 3 & 1.5 & \\
\hline Primary school & 51 & 25.1 & \\
\hline Lower secondary school & 62 & 30.5 & \\
\hline Upper secondary school & 78 & 38.4 & \\
\hline Tertiary level & 9 & 4.5 & \\
\hline \multicolumn{4}{|l|}{ Marital status } \\
\hline Single & 86 & 42.4 & \\
\hline Married & 117 & 57.6 & \\
\hline
\end{tabular}


INTERNATIONAL JOURNAL OF ACADEMIC RESEARCH IN BUSINESS AND SOCIAL SCIENCES

Vol. 8, No. 9, Sept. 2018, E-ISSN: 2222-6990 @ 2018 HRMARS

Number of household members

1-3 org

$45 \quad 22.2$

$4-5$ org

$71 \quad 35.0$

6-7 org

$53 \quad 26.1$

$>8$ org

34

16.7

\section{Fisheries activities background}

Table 2 demonstrates the respondents' fishery activities background. The mean score recorded for monthly income was RM1074.88 with $27.1 \%$ of them earning more than RM1, 000 per month. It was concluded that a majority of the respondents rely heavily on fishing activities as on average, $72.4 \%$ of their income came from marine resources. The respondents were considered as productive fishermen as on average, they managed to land more than $100 \mathrm{~kg}$ per week. With regard to experience, $6.9 \%$ of the respondents has more than 25 years of experience while another $28.1 \%$ have 16-25 years of experience in fishing activities. On average, the respondents spent 20 days in a month for their fishery activities with $20.7 \%$ spent more than 25 days fishing in a month. Most of them are equipped with vessels sizing from 21 to 22 feet and most of them used seines/nets as their main catching tool. Moreover, about $53.7 \%$ of them were found to use fisheries technologies within their fishing operation. 
INTERNATIONAL JOURNAL OF ACADEMIC RESEARCH IN BUSINESS AND SOCIAL SCIENCES Vol. 8, No. 9, Sept. 2018, E-ISSN: 2222-6990 @ 2018 HRMARS

Table 2: Fishery Activities Background

\begin{tabular}{|c|c|c|c|}
\hline Factor & Frequency & Percentage & Mean \\
\hline $\begin{array}{l}\text { Income generated from fisheries activities (per } \\
\text { month) }\end{array}$ & & & 1074.88 \\
\hline$<$ RM500 & 35 & 17.2 & \\
\hline RM501-RM750 & 35 & 17.2 & \\
\hline RM751-RM1000 & 78 & 38.4 & \\
\hline >RM1000 & 55 & 27.1 & \\
\hline Reliance on marine catches as income & & & 72.84 \\
\hline$<25$ & 9 & 4.4 & \\
\hline $25-50$ & 50 & 24.6 & \\
\hline $51-75$ & 39 & 19.2 & \\
\hline$>75$ & 105 & 51.7 & \\
\hline Total catches in a week ( $k g)$ & & & 105.46 \\
\hline$<25$ & 26 & 12.8 & \\
\hline $25-50$ & 46 & 22.7 & \\
\hline $51-100$ & 83 & 40.9 & \\
\hline$>100$ & 48 & 23.6 & \\
\hline Experience as a fisherman (years) & & & 12.78 \\
\hline$<5$ & 59 & 29.1 & \\
\hline $5-15$ & 73 & 36.0 & \\
\hline $16-25$ & 57 & 28.1 & \\
\hline$>25$ & 14 & 6.9 & \\
\hline Days spent for fishing operation (per month) & & & 20.10 \\
\hline$<15$ & 57 & 28.1 & \\
\hline $15-20$ & 72 & 35.5 & \\
\hline $21-25$ & 32 & 15.8 & \\
\hline$>25$ & 42 & 20.7 & \\
\hline Vessel Size (feet) & & & 23.14 \\
\hline$<20$ & 56 & 27.6 & \\
\hline $21-22$ & 74 & 36.5 & \\
\hline $23-25$ & 34 & 16.7 & \\
\hline$>25$ & 39 & 19.2 & \\
\hline \multicolumn{4}{|l|}{ Main catching tool } \\
\hline Portable traps & 7 & 3.4 & \\
\hline Seines/nets & 143 & 70.4 & \\
\hline Fishing rods & 36 & 17.7 & \\
\hline Others & 17 & 8.4 & \\
\hline \multicolumn{4}{|l|}{ Using fisheries technology? } \\
\hline Yes & 94 & 46.3 & \\
\hline
\end{tabular}


Adaptation capacity of small-scale youth fisherman towards climate change Small-scale youth fisherman adaptation towards climate change were measured based on 16 adaptation aspects; namely, 1) Perception of risk, 2) Ability to cope with change (financial and emotional flexibility), 3) Level of interest in adapting to change, 4) Ability to plan, to learn and reorganize, 5) Attachment to occupation, 6) Employability, 7) Family characteristics, 8) Attachment to place, 9) Business size and approaches, 10) Financial status and access to credit, 11) Livelihood diversity, 12) Local environmental knowledge, 13) Environmental awareness, values, and attitudes, 14) Perception of equity in accessing resources, 15) Access to technology, climate information, and skills and 16) Formal and informal networks.

The highest mean score recorded is their capacity to have deep attachment to place $(\mathrm{M}=4.75)$. It shows the importance of their residing area and to have attachment is not surprising as most of these respondents have long settled in their home areas. The second highest mean score was recorded on attachment to occupation and as most of them have worked at sea for a long period of time, it was no surprise that they were strongly attached to fisheries industry. The environmental awareness, values, and attitudes yielded the third highest mean score $(M=4.43)$. To have such finding is evident as most of them were experienced fishermen, thus it provides them with better sense of awareness, more appreciative towards the environment and have a positive attitude towards conserving the environment. The fourth highest mean score was recorded by formal and informal networks ( $M=$ 4.38). The respondents have a stronger adaptation ability in term of formal and informal networks. They have built strong formal networks with existing agencies and NGOs while their informal networks are heightened while doing informal activities in places of attraction such as the waqf, coffee stall, and mosque.

It is a concern that the aspect of employability recorded the lowest mean score which denotes the weakness of youth fishermen to seek other jobs related to fisheries activities. If this problem continues in the future, it would become a hardship for them if the sea continues to have problem in producing consistent resources for the coastal community. Business size and approach is another adaptation element that yielded a low mean score. Youth fishermen were found to have not kept any record of their selling activities and most of them relied on the middleman to market their catches. Livelihood diversity is another weak adaptation element. It indicates less or no alternative skills among youth fishermen and this is related to their shortcoming in the employability field and their high reliance on fisheries activities as the main income generating resource. 
INTERNATIONAL JOURNAL OF ACADEMIC RESEARCH IN BUSINESS AND SOCIAL SCIENCES Vol. 8, No. 9, Sept. 2018, E-ISSN: 2222-6990 @ 2018 HRMARS

Table 3: Adaptation capacity of small-scale youth fisherman towards climate change

Adaptation aspects

Mean score

Perception of risk

Ability to cope with change (financial and emotional flexibility)

Level of interest in adapting to change

3.80

Ability to plan, to learn and reorganize

3.89

Attachment to occupation

4.60

Employability

2.65

Family characteristics

3.30

Attachment to place

4.75

Business size and approaches

3.08

Financial status and access to credit

3.39

Livelihood diversity

3.20

Local environmental knowledge

4.02

Environmental awareness, values, and attitudes

4.43

Perception of equity in accessing resources

3.62

Access to technology, climate information, and skills

3.43

Formal and informal networks

4.38

\section{RECOMMENDATION}

Based on the resulted findings, the present study provides several adaptation strategies to increase the adaptation ability of small-scale youth fishermen towards the impact of climate change.

Exposure to advanced fisheries technology

As the challenges that occur with extreme weather and the degrading fishing resources are expected to worsen in the future, exposure to the use of advance fisheries technologies is seen as a good response. Advance fishing technologies such as sonar, echo sounder and GPS are capable of assisting youth fishermen in coping with the impacts of climate change.. Although most of them are not highly educated, according to Shaffril et al. (2016), they are more than willing to learn new technologies if the technology is user-friendly with no negative impact on marine sources, and if local agencies provide consistent workshops and courses.

Providing entrepreneurship opportunities

Local entrepreneurship-related programs should be exposed to youth fishermen. The introduction to an online marketing program dedicated to students such as "you can do it" should be adapted among fishermen in order for them to expand their marine catches marketing strategies and other smallmedium sea-based products. Having such program could help them get exposure to the business environment, which in turn allows them to sell their catches without reliance on the middlemen.

Good financial planning and management

Every year, the fishermen community will face monsoon season which obstructs them from operating their fishing routine for almost four months. To survive during this season would mean they should manage their finances better as their income will be lessen. By teaching them a good financial 
INTERNATIONAL JOURNAL OF ACADEMIC RESEARCH IN BUSINESS AND SOCIAL SCIENCES Vol. 8, No. 9, Sept. 2018, E-ISSN: 2222-6990 @ 2018 HRMARS

management practice could benefit them to lead a sustain living even during the hard times, and such financial planning should frequently be exposed to them, especially among youth fishermen.

Financial assistance

Financial assistance is important for pre and post-adaptation among youth fishermen. It will strengthen their readiness to overcome the impacts of climate change and expedite their recovery process. To realize this, agencies such as Lembaga Kemajuan Ikan Malaysia (LKIM), Persatuan Nelayan Kawasan (PNK) and Agrobank have an important role in offering credit aids needed by youth fishermen. Nevertheless, according to Shaffril et al. (2017), in relation to bureaucracy, it needs to be lessened as it will decrease fishermen's interest to apply any of the financial assistance.

\section{CONCLUSION}

Climate change phenomenon is not new and it is expected to worsen in the future. It is expected to expose fishermen to higher fisheries operation risks. Furthermore, climate change is also found to reduce the quality, quantity, and habitat of marine fauna. To overcome these problems, increase adaptation among the community especially those who rely on nature stability is essential. This study fulfil its objectives by concluding that youth fishermen's strength in adaptation were supported by their strong attachment to place, attachment to the area, environmental awareness, values and attitudes and formal and informal networks. Meanwhile, they are seen to be weak in adaptation aspects related to employability, business size, and approach and livelihood diversity. It is suggested that small-scale youth fishermen adaptation ability can be strengthened by focusing on four main issues: (1) exposure to advance fisheries technologies, (2) providing entrepreneurship opportunities, (3) good financial planning and management, and (4) free from bureaucracy financial assistance.

\section{ACKNOWLEDGEMENT}

The research team would like to thank Universiti Putra Malaysia for providing Putra Grant Scheme for this study (IPB - GP-IPB/2014/9441301)

\section{REFFERENCES}

Abu Samah, A., Hamdan, M.E., Abu Samah, B., Hamzah, A., \& and Shaffril, H.A.M. (2016). Adaptation towards climate change among small-scale fishermen: $A$ comparison between the east coast and west coast fishermen in Peninsular Malaysia. The Social Science, 11 (14), 3458-3462.

Badjeck, M.-C., Allison, E.H., Ashley, S.H., \& Nicholas, K.D. (2009). Impacts of climate variability and change on fishery based livelihood. Marine Policy, 3, 375-383.

Shaffril, H.A.M., Abu Samah, A., \& D'Silva, J.L. (2017). Adapting towards climate change impacts: Strategies for small-scale fishermen in Malaysia. Marine Policy, 81, 196-201.

Shaffril, H.A.M., Abu Samah, A., \& D'Silva, J.L. (2017). Climate change: Social adaptation strategies for fishermen. Marine Policy, 81, 256-261. 
INTERNATIONAL JOURNAL OF ACADEMIC RESEARCH IN BUSINESS AND SOCIAL SCIENCES Vol. 8, No. 9, Sept. 2018, E-ISSN: 2222-6990 (C) 2018 HRMARS

Shaffril, H.A.M., D'Silva, J.L., Kamaruddin, N., \& Omar, S.Z. (2015). The coastal community awareness towards the climate change in Malaysia. International Journal of Climate Change Strategies and Management, 7 (4), 516-531.

D'Silva, J.L., Shaffril, H.A.M., Abu Samah, B., \& Uli, J. (2012). Assessment of social adaptation capacity of Malaysian fishermen to climate change. Journal of Applied Sciences, 12 (9), 876-881.

Muhammad, M., Idris, K., Helmy Ariffin, E., Shaffril, H.A.M., Abu Samah, B., \& Suandi, T. (2016). The impact of climate change on small-scale fishermen in Malaysia. The Social Sciences, 11 (13), 3352-3356.

Ministry of Natural Resources and Environment Malaysia (NRE) (2010). National Policy on Climate Change. NRE.

Intergovernmental Panel on Climate Change (IPCC). (2007). Contribution of Working Group II to the Fourth Assessment Report of the Intergovernmental Panel on Climate Change, 2007, M.L. Parry, O.F. Canziani, J.P. Palutikof, P.J. van der Linden and C.E. Hanson (eds) Cambridge University Press, Cambridge, UK and New York, NY.

Kwan, M.S., Tanggang, F.T., \& Juneng, L. (2011). Projected changes of future climate extremes in Malaysia. Paper presented at National Symposium on Climate Change Adaptation, 16-17 November 2011. Putrajaya, Malaysia.

Roessig, J.M., Woodley, C.M., Cech, J.J., \& Hansen, L.J. (2004). Effects of global climate change on marine and estuaries fisheries. Review in Fish Biology and Fisheries, 14 (2), 251-275.

Suhaila, J., Deni, S.M., Wan Zin, W.Z. \& Jemain, A.A. (2010). Spatial patterns and trends of daily rainfall regime in Peninsular Malaysia during the southwest and northeast monsoon: 1975-2004. Meteorology and Atmospheric Physics, 110, 1-18.

Tanggang, F.T., Juneng, L., Salimun, E., Sei, K.M., Le, L.J., \& , H. (2012). Climate change and variability over Malaysia: gaps in science and research information, Sains Malays. 41 (11) 1355-1366. 